\title{
Access to Finance and Performance of Small Firms In South Africa: The Moderating Effect Of Financial Literacy
}

\author{
OLAWALE FATOKI \\ Department of Business Management, University of Limpopo, Private Bag X1314, \\ Sovenga, 0727, SOUTH AFRICA
}

\begin{abstract}
The failure rate of small medium and micro enterprises (SMMEs) is very high in South Africa. One of the challenges faced by SMMEs is inaccessibility to external finance. There is a general low level of financial literacy amongst small business owners in South Africa leading to illinformed financial decisions. Financial literacy is an important knowledge resource for financial decision-making but little research has focused on how financial literacy affects the performance of SMMEs. The aim of the study was to examine if financial literacy moderates the relationship between access to finance and performance of SMMEs in South Africa. The cross-sectional survey method was used for data collection in a quantitative study. Descriptive statistics, Pearson correlation and

hierarchical regression were used for data analysis. The Cronbach's alpha was used as a measure of reliability. The findings indicated that the relationship between access to finance and financial literacy is significant. The findings also showed that financial literacy moderates the relationship between access to finance and performance of SMMEs. Empirically, the study added to the body of literature on financial literacy, access to finance and performance of SMMEs. Practically, recommendations to improve the financial literacy of SMMEs are suggested. Keywords: financial literacy, access to finance, performance, SMMEs, moderating, South Africa
\end{abstract}

Received: June 3, 2020. Revised: December 14, 2020. Accepted: January 6, 2021. Published: January 11, 2021

\section{Introduction}

Small and medium and micro enterprises (SMMEs) play an important role in the economies of countries around the world. SMMEs generate employment and value added and contribute to the gross domestic product (GDP). SMMEs are crucial to the efforts of governments to achieve a more inclusive growth. In the Organisation for Economic Co-operation and Development (OECD) countries, SMMEs are the main form of enterprise, accounting for approximately $99 \%$ of all firms. SMMEs contribute about $70 \%$ of jobs and generate between $50 \%$ and $60 \%$ of value added [1]. In developing countries, SMMEs are a major contributor to employment generation, economic empowerment and social wellbeing of the majority of the citizens. SMMEs contribute about $40 \%$ of the GDP and $60 \%$ of total employment in developing economies. It is estimated that 600 million jobs will be needed by 2030 to absorb the increasing global workforce and this makes SMME development a major priority for many governments around the world [2, 3]. In South Africa, the SMME sector accounts for $98.5 \%$ of all firms but only firms contribute $28 \%$ of all jobs [4]. One of the reasons for the low contributions of SMMEs to job creation in
South Africa is their high failure rate. This is because when SMMEs fail, jobs are lost. The high failure rate of SMMEs paints a bleak picture of the sector's ability to contribute significantly to job creation, the reduction of poverty and income inequality and economic growth in many developing countries. SMMEs continue to be as economically fragile and about $70 \%$ of emerging small businesses fail within the first two years of operation. The number of SMMEs and their contribution to employment continue to decline yearly. Thus, South Africa's SMME sector is an outlier internationally in respect of its contribution to employment and the GDP $[4,5]$. The growth of SMMEs is hindered by many factors including lack of managerial skills, regulations and inaccessibility to external finance [6]. SMMEs suffer change from a financing gap which means that that there are significant numbers of SMMEs that cannot obtain finance from the formal financial system. Access to finance is the second most reported obstacle to the growth of SMMEs in developing countries $[2,7]$. Most SMMEs are managed by the owners and their success or failure is dependent on the resources available to the owners. These resources include financial literacy [3, 8,]. According to [9], financial literacy measures how well an individual can understand and use personal finance-related 
information. Financial literacy includes the ability and confidence of an individual to use his/her financial knowledge to make financial decisions. There is a general low level of financial literacy amongst individuals and small business owners in South Africa leading to ill-informed financial decisions. The role of SMMEs in creating employment and stimulating economic growth has been hampered by lack of access to finance from formal financial institutions and this can be attributed to the level of financial literacy amongst SMME owners and managers [10, 11]. However, research on the role of financial literacy in transforming access to finance to improved performance is limited [12]. According to [13], extant research generally agrees that SMMEs have constrained access to external finance. However, most studies have focused on supply side institutions, information asymmetry and the use of collateral to reduce default risk. This approach fails to take into consideration the effect of financial literacy in improving access to finance and performance of SMMEs. [14] point out that the role of knowledge-based resources in improving the sustainability of small businesses is a current topic of debate. Financial literacy is an important knowledge resource for financial decision-making but little research has focused on how financial literacy affects the performance of SMMEs. The aim of this study is to investigate the effect of financial literacy on access to finance and performance relationship of SMMEs. Thus, this study will examine if financial literacy moderates the relationship between access to finance and performance of SMMEs in South Africa. To achieve the main objective, the study will also investigate the impact of access to external finance on performance, the effect of financial literacy on access to finance and the influence of financial literacy on the performance of SMMEs. This research will contribute to the literature on financial literacy, access to finance and performance of SMMEs in the following ways. First, limited studies [11, 12] have examined the moderating effect of financial literacy on access to finance and performance and to the best of the author's knowledge none from the South Africa. The findings of this study will extend research on how financial literacy affects access to finance and performance of SMMEs from a developing country perspective where extant research has been very limited. Second the research findings will provide SMME owner-managers and policymakers with information on how financial education and skills can improve the performance of SMMEs. The study is organised as follows: Section two will provide the review of the literature and the development of the conceptual framework and hypotheses. Section three will focus on the research methodology and measures. The presentation of results and discussion will be done in sections four and five. The conclusion, implications, limitations and areas for further study will be presented in section six.

\section{Problem formulation}

\subsection{Definition of small, medium and micro enterprises in South Africa}

The National Small Business Act of 1996, as revised in 2003, defines a small business as "a separate distinct entity including cooperative enterprises and non-governmental organisations managed by one owner or more, including branches or subsidiaries if any is predominately carried out in any sector or subsector of the economy mentioned in the schedule of size standards". There are three enterprise classes for SMEs in South Africa. These are micro, small and medium. The quantitative definition focuses on the number of employees and total annual turnover [15] (Government Gazette, 2019). The number of employees is one of the indicators that is used to classify SMMEs in South Africa. Quantitatively, a micro enterprise will have between 0 and 10 employees, small enterprises between 11 and 50 employees, and medium enterprises between 51 and 250 employees [15].

\subsection{Access to debt finance and performance of SMMEs}

[16] remark that access to debt finance is linked with the ability of an enterprise to obtain financial services. Access to external finance is an important factor in ensuring business growth through the financing of existing and new investment projects. An efficient investment can only be achieved when a firm does not face credit obstacles. [17] points out that the majority of small 
businesses in countries in the South African Development Corporation (SADC) depend on owners' capital especially at the start-up stage. However, owners' capital is often inadequate and limits the operation of SMMEs. This underfunding can lead to stagnation or failure. The major sources of external finance are equity and debt. However, access to equity is limited for many SMMEs in South Africa [18]. [19] agree that the lack of external equity makes many SMEs dependent on debt financing. Paradoxically, access to debt finance is also limited for SMMEs [20]. Therefore, lack of access to finance is a serious impediment to start-up and growth of SMMEs. [21] find that access to debt finance positively impacts on the performance of Zimbabwean SMMEs. According to [16], one of the ways that access to finance can impact on firm performance is through improvement in productivity. The results of the study show that improving financial accessibility has a significant positive impact on the total factor productivity of SMMEs. [22] also find a positive relationship between access to finance, firm productivity and export intensity of small firms. SMMEs need external finance for daily operations and to invest in profitable projects and technologies that can improve their competitiveness. Therefore, financing constraints can hamper the performance of SMMEs. It is hypothesised (H1) that there is a significant positive relationship between access to finance and the performance of SMMEs.

\subsection{Financial literacy and access to debt finance by SMMEs}

Huston [9] describes financial literacy as measuring how well an individual can understand and use personal finance-related information. [32] defines a financially-literate SMME owner as one that has an adequate level of personal finance skills and an appropriate level of understanding of functional financial management systems. [8] find that the financial literacy of is one of the important factors in the understanding and use of financial services by SMMEs. A low level of financial literacy can prevent SMME owner from understanding and assessing financial products from financial institutions. Financial literacy positively affects the production of financial statements. A small business that produces financial statements has a higher probability of loan approval and repayment and a lower probability of failure [13, 23, 24]. Financial literacy can help the owners of SMMEs to understand both traditional and alternative financing sources like crowdfunding and to diversify financial instruments [25]. Consequently, it is hypothesised $(\mathrm{H} 2)$ that there is a significant positive relationship between financial literacy and access to finance by SMMEs.

\subsection{Financial literacy and performance of SMMEs}

[26] claim that a good financial foundation of the owners of SMMEs is a significant barometer of success. Financial literacy improves access to finance and success of SMMEs. The theoretical link between financial literacy and performance can be linked to the Resource Based View (RBV) theory [27]. According to the RBV, managers should focus on a firm's internal resources in order to identify those capabilities, competencies and assets that can bring superior competitive advantages. Tangible resources include financial capital and physical capital whilst intangible resources consist of knowledge, skills and experiences [28]. Financial literacy is a resource that a firm can utilise to generate competitive advantage [29]. Financial literacy influences a firm's selection, use and management of financial assets and the effectiveness of financing decisions and strategy $[12,26]$. Good financing and investment decisions by financially literate owners can impact on the liquidity, solvency and profitability SMMEs. It is hypothesised $(\mathrm{H} 3)$ that there is a significant positive relationship between financial literacy and the performance of SMMEs.

\subsection{Financial literacy moderates the relationship between access to debt finance and performance of SMMEs}

[12] assert that the financial capability of firm owners is a resource that can be regarded as valuable, rare and inimitable and influences both access to debt finance and performance of SMMEs. Access to finance can be linked to dynamic capabilities that can affect firm performance. A high degree of financial 
literacy can give small business owners access to knowledge and information about how to obtain finance which in turn can lead to competitive advantage and superior performance. Lack of financial literacy can lead to bad financial decisions with negative consequences on a firm's operation, financial structure and mission [13]. According to [12], financial literacy positively enhances access to finance and performance relationship of small businesses in Ghana. Financial literacy can enable the effective conversion of access to finance into improved firm performance. [11] find a significant positive moderating effect of financial literacy in the relationship between access to finance and growth of SMMEs in Uganda. The application of financial knowledge and skills can help SMMEs to obtain financial resources, generate competitive advantage and improve performance. It is hypothesised (H4) that financial literacy moderates the relationship between access to finance and performance of SMMEs.

\subsection{Research methodology}

The study used a positivistic research paradigm and a quantitative research approach. Data was collected through the cross-sectional survey approach. The population comprised of the owners of all SMMEs in the Gauteng and Limpopo Provinces of South Africa. The survey was conducted in the Central Business Districts of Johannesburg (Gauteng Province) and Polokwane (Limpopo Province) of South Africa. The areas were used for the survey because they contain a large number of SMMEs. Currently, there is no national database or list of small businesses in South Africa or in the Gauteng or Limpopo Provinces, therefore the purposive sampling technique was used to identify survey participants. The use of non-probability sampling method is consistent with previous empirical studies on SMMEs in South Africa $[18,34]$. The phone numbers and Email addresses of the participants were obtained during the distribution of questionnaires. Three field agents assisted in the data collection process and data collection took place between May and September, 2019. Repeated phone calls, emails and visits were made to the participants to complete the questionnaire. If the questionnaire is not completed after two months, it is treated as non-response. A pilot study was conducted on the survey instrument used in this research with 30 SMME owners in order to ensure face and content validity. The pilot study was done before the actual data collection and the respondents of the pilot study did not participate in the actual survey. The questionnaire was divided into four parts: (1) biographical information; (2) access to finance (3) financial literacy and (4) firm financial performance. Descriptive statistics, Pearson correlation and hierarchical regression were used for data analysis. The Cronbach's alpha was used as a measure of reliability. For ethical, consideration, the purpose of the study was clearly specified in the questionnaire, participation was voluntary, and confidentiality and anonymity were ensured. The variables in the study were measured as follows: Subjective questions were used to measure the performance of SMMEs. Three questions (growth in profitability, turnover (sales) market share) and anchored on the five point Likert scale (1 significant decline" to "5 significant increase" in the prior year) were used to measure financial performance. The responses to the three questions are summed to obtain the average financial performance. This is consistent with similar studies [12, 26], The Cronbach's alpha of the scale was .76, indicating high reliability of scale [30]. Four questions were used to measure the financial literacy of SMME owners. (1) we prepare monthly company financial statement (income statement and balance sheet); (2) we review monthly financial statements; (3) we perform financial analysis on monthly financial statements; and (4) we have an understanding of the company's gross profit ratio and its contribution to the overall profit. A five-point Likert scale with anchored on "1 'strongly disagree' and ' 5 strongly agree' was used to measure financial literacy. The responses to the four questions are summed to obtain the average financial literacy. This is consistent with studies $[12,13]$. The Cronbach's alpha of the scale was .80 , indicating high reliability of scale. Two questions were used to measure access to debt finance (1) access to bank credit and (2) access to trade credit. A five-point Likert scale with anchored on "1 'totally dissatisfied and 5 totally satisfied was used to measure access to debt finance [33]. The 
responses to the two questions are summed to obtain access to debt finance. The Cronbach's

\section{Problem solution}

\subsection{Response rate and biographical details}

Table 1. Biographical information of the respondents. alpha of the scale was 0.77 , indicating high reliability scale.

\begin{tabular}{|c|c|}
\hline Biographical Characteristics & Frequency $(N=175)$ \\
\hline \multicolumn{2}{|c|}{$\begin{array}{r}\text { Educational qualification of owner/manager } \\
\text { Frequency }\end{array}$} \\
\hline Below Matric & 42 \\
\hline Matric & 91 \\
\hline Post-Matric qualifications & 42 \\
\hline \multicolumn{2}{|l|}{ Gender } \\
\hline Female & 76 \\
\hline Male & 99 \\
\hline \multicolumn{2}{|l|}{ Age of the owner (years) } \\
\hline Less than 20 & 0 \\
\hline $20-30$ & 43 \\
\hline $31-40$ & 83 \\
\hline $41-50$ & 29 \\
\hline Above 50 & 20 \\
\hline \multicolumn{2}{|l|}{ Age of the firm (years) } \\
\hline $1-5$ & 74 \\
\hline $6-10$ & 67 \\
\hline Above 10 years & 34 \\
\hline \multicolumn{2}{|l|}{ Number of employees } \\
\hline $0-10$ & 114 \\
\hline 11-50 employees & 61 \\
\hline \multicolumn{2}{|l|}{ Sector of the respondents } \\
\hline Retail & \\
\hline Service & \\
\hline
\end{tabular}

Four hundred and fifty questionnaires were distributed to small business owners and one hundred and seventy-five questionnaires were returned. The response rate was $39 \%$. The biographical details as presented in table 1 included both owner and firm characteristics. Owner characteristics included the level of education, gender and age of the respondents. Firm characteristics included the age of the firm, the number of employees and the sector. 
The results indicated that the majority of respondents in the survey are male, with Matric qualification and in the 31-40 age group. In additions, most of the firms that participated in the survey have been in existence for between six and ten years, employ between 0 and 10 employees and are thus micro businesses according to the National Small Business Act. In addition, the majority of firms that participated in the survey are in the retail sector.

\subsection{Descriptive statistics and Pearson's zero order correlation matrix}

Table 2 Descriptive statistics and Pearson's zero order correlation matrix

\begin{tabular}{|c|c|c|c|c|c|}
\hline Variable & Mean & $\begin{array}{l}\text { Standard } \\
\text { deviation }\end{array}$ & 1 & 2 & 3 \\
\hline $\begin{array}{l}\text { Access to debt } \\
\text { finance }\end{array}$ & 3.405 & 1.014 & 1 & & \\
\hline $\begin{array}{l}\text { Financial } \\
\text { literacy }\end{array}$ & 2.810 & 1.113 & $0.599 *$ & 1 & \\
\hline Performance & 3.350 & 1.026 & $0.504 *$ & $0.755^{* *}$ & 1 \\
\hline
\end{tabular}

*significant at 5\%; ** significant at $1 \%$.

\subsection{Hierarchical regression results}

Table 3 Hierarchical regression results

\begin{tabular}{|l|l|l|l|l|l|}
\hline Variable & Model 1 & $\begin{array}{l}\text { Model 2 } \\
\text { Performance }\end{array}$ & Model 3 & VIF & Tolerance \\
\hline Constant & 2.684 & 1.375 & 0.729 & & \\
\hline $\begin{array}{l}\text { Access } \\
\text { finance } \\
\text { (main effect) }\end{array}$ & 0.199 & $0.206^{*}$ & $0.183^{* *}$ & 1.026 & 0.682 \\
\hline $\begin{array}{l}\text { Financial } \\
\text { literacy } \\
\text { (moderator) }\end{array}$ & & $0.708^{*}$ & $0.491^{* *}$ & 1.137 & 0.739 \\
\hline Interaction term & & & $0.162^{* *}$ & 1.119 & \\
\hline $\mathrm{R}^{2}$ & 0.052 & 0.178 & 0.253 & & \\
\hline Change in $\mathrm{R}^{2}$ & 0.164 & 0.075 & & & \\
\hline Change in F & $5.947^{*}$ & $28.715^{* *}$ & 0.275 & & \\
\hline
\end{tabular}

*significant at 5\%; ** significant at $1 \%$

Table 2 depicts the results of the descriptive statistics and Pearson correlation. Matrix. The results indicated that the mean of financial literacy is 2.810 while the means of access to debt finance (3.505) and performance (3.550). The standard deviations of all the constructs ranged from 1.014 to 1.13 reflecting significant variability in the data set. The results of Pearson correlation and hierarchical regression. Collinerarity statistics show that tolerance is $>0.1$ and VIF $<10$ for all variables. The results of Pearson correlation $(\mathrm{r}=0.504, \mathrm{p}<0.05)$ and hierarchical regression $(\beta=0.183, \mathrm{p}<0.01)$ indicate a significant positive relationship between access to debt finance and performance of SMMEs. $\mathrm{H} 1$ is supported. In addition, the results $(\mathrm{r}=0.599 \mathrm{p}$ $<0.05)$ and $\beta=0.708, \mathrm{p}<0.05$ ) indicate a significant positive relationship between finance literacy and access to debt finance by SMMEs. $\mathrm{H} 2$ is supported. The results $(\mathrm{r}=0.755, \mathrm{p}<0.01)$ and $(\beta=0.491, \mathrm{p}<0.01)$ indicate a significant positive relationship between financial literacy and performance of SMMEs. H3 is supported. The hierarchical regression (table 3) was used to show the effects of both the independent (access to finance and moderator (financial literacy) variables on the dependent variable (performance). The study followed the 
mediation steps as analysed by [35, 36, 37]. The results $(\beta=0.162, \mathrm{p}<0.01)$ show that the interaction effect between financial literacy and access to finance is significantly positive. In addition, the results indicate that the interactive term of including financial literacy as a moderator increases the main effect (access to finance) by $7.5 \%$ to explain variation in performance (change in $\mathrm{R}^{2}=$ 0.075). Also the inclusion of the interactive term between access to finance and financial literacy boosted the predictive power of access to finance from 0.178 to 0.253 (a change of $7.5 \%)$. Thus it can be concluded that financial literacy significantly moderates the relationship between access to finance and performance of SMMEs. H4 is supported.

\subsection{Discussion}

The study examined if financial literacy moderates the relationship between access to debt finance and performance of SMMEs in South Africa. In addition, the study investigated the impact of access to external finance on performance, the effect of financial literacy on access to finance and the influence of financial literacy on the performance of SMMEs in South Africa. The findings of the study showed a significant positive relationship between access to debt finance and performance of SMMEs. Hypothesis one of the study is accepted. of the study is supported. The results support a positive relationship between access to finance and performance of SMEs. This is especially important because many SMMEs are unable to secure adequate debt finance to fund projects with positive present values. Access to external finance is an important factor in ensuring business growth through the financing of existing and new investment projects. An efficient investment can only be achieved only when a firm does not face credit obstacles. In addition, access to equity capital is also limited for SMMEs and the availability of debt finance is important to finance growthenhancing projects. The findings are consistent with the results of previous empirical studies $[16,21,22]$ that access to external finance is an important factor in ensuring business growth through the financing of existing and new investment projects. Therefore, inaccessibility to external finance is a serious impediment to the growth of SMMEs [31].
The findings of the study showed a significant positive relationship between financial literacy and access to finance by SMMEs. Hypothesis two of the study is supported. The findings are consistent with the results of previous empirical studies. [8] find that the financial literacy of is one of the important factors in the use of financial services by SMMEs. Financial literacy positively affects the production of financial statements and leads to a higher probability of loan approval. Financial literacy can help the owners of SMMEs to understand both traditional and alternative financing sources [25]. The findings of the study showed a significant positive relationship between financial literacy and the performance of SMMEs. Hypothesis three of the study is supported. [26] establish that financial literacy improves access to finance and success of SMMEs. Small business owners can use financial literacy to obtain financial resources which can help to generate competitive advantage and improve performance [29]. In addition, financial literacy influences the selection, use and management of financial assets and the effectiveness of the financing decisions [26]. The findings of the study indicated that financial literacy moderates the relationship between access to finance and performance of SMMEs in South Africa. Hypothesis four of the study is supported. [12] find that financial literacy positively enhances the access to finance and performance relationship of small businesses in Ghana. Financial literacy enables the effective conversion of access to finance into improved performance. The results of the study by [11] also reveal a significantly positive moderating effect of financial literacy in the relationship between access to finance and growth of SMMEs in Uganda. The application of financial knowledge and skills can help SMMEs to obtain financial resources which leads to improved performance.

\section{Conclusion}

The SMME sector although accounts for $98.5 \%$ of all but only contribute $28 \%$ of all jobs in South Africa. One of the reasons for the low contributions of SMMEs to job creation in South Africa is their high failure rate. The performance of SMMEs is hindered by many factors including lack of access to 
external finance. Therefore, it is important to examine the factors that can improve the performance of SMMEs. The study examined if financial literacy moderates the relationship between access to finance and performance of SMMEs in South Africa. In addition, the study investigated the impact of access to external finance on performance, the effect of financial literacy on access to finance and the influence of financial literacy on the performance of SMMEs in South Africa. The findings indicated that the relationship between financial literacy and access to finance by SMMEs is significant. The findings also showed that financial literacy moderates the relationship between access to finance and performance of SMMEs.

The study makes an empirical contribution to the literature on financial literacy, access to finance and performance of SMMEs. The findings of the study showed that to improve access to debt and performance of SMMEs, the financial literacy of the business owner is important. Empirically, the body adds to the body of literature on the relationship between financial literacy and access to debt and performance of SMMEs in developing countries. The study has some practical implications and the findings can assist
SMME owners and government to better comprehend how to promote financial literacy. Owners have to be proactive and attend courses on financial management and literacy. Many universities in South Africa have short courses in their curriculum that can assist SMMEs with financial management skills. SMME owners can also partner with banks, accountants and bookkeepers to help them learn how to use financial management software. SMMEs can also partner with governmental and non-governmental organisations that support entrepreneurship for training on financial literacy. The study has some limitations. The non-probability sampling method was used and the data collected may be biased and represent only the opinions of the respondents of the study. Therefore, care should be applied in generalising the findings of the study. The cross-sectional survey approach used by the study cannot be used to analyse behaviour over a period of time and limits the ability to determine cause and effect. Other studies can explore the effect of demographic variables of SMME owners on financial literacy. A longitudinal study focusing on the same concepts will help to improve cause and effect relationship. 


\section{References}

[1] Organisation for Economic Co-operation and Development, 2017. Enhancing the contributions of SMEs in a global and digitalised economy. Online: https://www.oecd.org/industry/C-MIN-20178-EN.pdf. (Accessed 20 June 2019)

[2] World Bank 2018. Unlocking the Potential of SMEs with an Innovative, Risk-Sharing Financing Solution. https://www.worldbank.org/en/news/feature/2 018/09/20/unlocking-the-potential-of-smeswith-an-innovative-risk-sharing-financingsolution (Accessed 20 June 2019)

[3] Agyei, SK. Culture, financial literacy, and SME performance in Ghana. Cogent Economics \& Finance, Vol. 6, No. 1, 2018, pp. 1-16.

[4] Small Business Institute, 2018. The number of formal micros, small \& medium businesses in South Africa. https://www.smallbusinessinstitute.co.za/wpcontent/uploads/2018/10/SBIbaselineAlert1fin al.pdf (Accessed 20 June 2019)

[5] Small Enterprise Development Agency, 2018. SMME Quarterly Update 1st Quarter 2018.

http://www.seda.org.za/Publications/Publicatio ns/SMME\%20Quarterly\%202018-Q1.pdf (Accessed 20 June 2019)

[6] Mabula, JB., Ping, HD. Use of Technology and SME Managers' Financial Literacy in Developing Economies. ICEBT 2018: Proceedings of the 2nd International Conference on E-Education, E-Business and E-Technology. July 2018 ,pp. 145-152.

[7] Rupeika-Apogaa, R., Danovi, A. Availability of Alternative Financial Resources for SMEs as a Critical Part of the Entrepreneurial Eco-System: Latvia and Italy. 7th International Conference, The Economies of Balkan and Eastern Europe Countries in the changed world, EBEEC 2015, 2015, May 810 ,

[8] Nunoo, J., Andoh, F.K. Sustaining small and medium enterprises through financial services utilization: Does financial literacy matter? A paper presented at the Agricultural \& Applied Economics Association's 2012
AAEA Annual Meeting, Seattle, Washington, $12-14$

[9] Huston, SJ. Measuring Financial Literacy. Journal of Consumer Affairs. Vol. 44, No. 2, 2010, pp.296-316.

[10] Fatoki, O. The Financial Literacy of Micro Entrepreneurs in South Africa. Journal of Social Science, Vol. 40, No 2, 2014, pp. 151-158.

[11] Bongomin, G., Ntayi, J., Munene, J., Akol, C. The relationship between access to finance and growth of SMEs in developing economies: Financial literacy as a moderator. Review of International Business. Strategy, Vol.27, 2017. pp. 520-538.

[12] Adomako, S., Danso, A., Damoah, JO. The moderating influence of financial literacy on the relationship between access to finance and firm growth in Ghana, Venture Capital, Vol. 18, No. 1, 2015, pp. 43-61

[13] Hussain, J., Salia, S., Karim, A. Is knowledge that powerful? Financial literacy and access to finance: An analysis of enterprises in the UK. Journal of. Small Business and. Enterprise. Development, Vol. 25, 2018, pp. 985-1003

[14] Kulathunga, K., Ye, J. How Does Financial Literacy Promote Sustainability in SMEs? A Developing Country Perspective, Sustainability, Vol. 11, pp. 2019, 2990.

[15] Government Gazette, 2019. Revised Schedule 1 of the National Definition of Small Enterprise in South Africa https://www.gov.za/sites/default/files/gcis_doc ument/201903/423041gon399.pdf (accessed on 25 April 2019).

[16] Giang, M, Trung, B., Yoshida, Y., Xuan, T., Que, M. The Causal Effect of Access to Finance on Productivity of Small and Medium Enterprises in Vietnam. Sustainability. Vol. 11, 2019, pp.5451-5462.

[17] FinMark Trust 2017. Small business performance: Does access to finance matter? http://www.finmark.org.za/wpcontent/uploads/2017/05/policy-paper-msmeaccess-to-finance.pdf (accessed on 25 April 2019). 
[18] Shava, H. Impact of gender on small and medium-sized entities' access to venture capital in South Africa. South African Journal of Economics and Management Sciences, Vol. 21, No. 1, 2018, pp. 1738-1750.

[19] Blumberg, BF., Letterie, WA. Business Starters and Credit Rationing. Small Business Economics, Vol. 30, No. 2, 2008, pp. 187-200.

[20] Osano, H., Languitone, H. Factors influencing access to finance by SMEs in Mozambique: case of SMEs in Maputo central business district. Journal of Innovation and Entrepreneurship, Vol. 5, No. 13, 2016, pp. 110.

[21] Sibanda, K, Hove Sibanda, P and Shava, $\mathrm{H}$. The impact of SME access to finance and performance on exporting behaviour at firm level: A case of furniture manufacturing SMEs in Zimbabwe. Acta Commercii, Vol. 18, No 1, 2018, pp. 1-13.

[22] Tsoukatos, E. Lemonakis, C \& Garefalakis, A. Access to finance and performance of SMEs manufacturing firms: Evidence from EU, Scandinavian and Balkan countries. September 2015. 8th Annual Euromed Academy of Business Conference

[23] Kotzè, L., Smit, A. Personal financial literacy and personal debt management: The potential relationships with new venture creation. South. African. Journal of Entrepreneurship and Small Business Management, Vol. 1, 2018, pp. 35-50.

[24] Wise, S. The impact of financial literacy on new venture survival. International. Journal of Business Management, Vol. 8, 2013, pp. 30-39.

[25] Organisation for Economic Co-operation and Development, 2018. Financing SMEs and Entrepreneurs.

https://www.oecd.org/cfe/smes/HighlightsFinancing-SMEs-and-Entrepreneurs-2018.pdf (accessed on 13 July 2019).

[26] Agyapong, D., Attram, AB. Effect on owner-manager's financial literacy on the performance of SMEs in the Cape Coast Metropolis in Ghana. Journal of Global Entrepreneurship Research, Vol. 9, No. 67, 2019, pp. 1-13.
[27] Barney, J. Firm resources and sustained competitive advantage. Journal of Management, 17, 1991, 99-120

[28] Eniola, AA., Ektebang, H. SME firms performance in Nigeria: Competitive advantage and its impact. International Journal of Research Studies in Management, Vol.3, 2014, pp. 75-78

[29] Abdulsaleh, AM., Worthington, A. Small and Medium-Sized Enterprises Financing: A Review of Literature. International Journal of Business and Management, Vol. 8, No.14, 2013, pp. 36-54

[30] Nunnally, J.C., Bernstein, I.H., Psychometric Theory. McGraw-Hill, New York. 1994.

[31] FinMark Trust 2015. Financial Access and SME Size in South Africa. http://www.finmark.org.za/wpcontent/uploads/2016/01/Rep_FinancialAccess-and-SME-Size-in-SA_Dec2015-1.pdf (accessed on 15 July 2019).

[32] Banking Association of South Africa/ SME Financial literacy in South Africa. https://www.banking.org.za/what-we-do/sme/ (accessed on 13 July 2019).

[33] European Central Bank 2009. Survey on the access to finance of SMEs, https://www.ecb.europa.eu/stats/accesstofinan cesofenterprises/pdf/questionnaire/ecb.safeq20 09H1.en.pdf (accessed on 11 July 2019).

[34] Farrington, SM, Psychological wellbeing and perceived financial performance: An SME perspective. South African Journal of Business Management, Vol. 48, No.4, 2017, pp. 47-56.

[35] Baron RM., Kenny DA. The moderatormediator variable distinction in social psychological research: Conceptual, strategic, and statistical considerations. Journal of Personality and Social Psychology, Vol.51, 1986, pp. 1173-1182.

[36] James LR \& Brett JM. Mediators, moderators and tests for mediation. Journal of Applied Psychology, Vol. 69, 1984, pp. 307321.

[37] Judd CM \& Kenny DA. Process analysis: Estimating mediation in treatment evaluations. Evaluation Review, Vol.5, 1981, pp.602-619.

Creative Commons Attribution License 4.0 (Attribution 4.0 International, CC BY 4.0)

This article is published under the terms of the Creative Commons Attribution License 4.0

https://creativecommons.org/licenses/by/4.0/deed.en_US Volume 18, 2021 